\title{
A Friend in Need? The Sino-Russian Relationship Under the Coronavirus Crisis in Twitter: a Russian Perspective
}

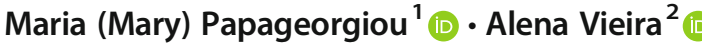

Received: 20 November 2020 / Accepted: 22 March 2021/ Published online: 15 April 2021

(C) The Author(s), under exclusive licence to Springer Nature B.V. 2021

\begin{abstract}
The paper focuses on the COVID-19 as a stress test to the Sino-Russian strategic partnership: has it driven Russia and China closer together, farther apart, or made no difference? Employing content analysis of official Russian discourse as expressed by the Kremlin, the Government, and the Ministry of Foreign Affairs (MFA), both via their official web pages (104 online publications) and Twitter accounts (260 tweets), this study focuses on the Russian twiplomacy as a more suitable mean to reflect the real-time changes of an evolving crisis. The analysis demonstrates that the SinoRussian relationship extends beyond the "axis of convenience." It does not, however, correspond to the support expected from a consolidated (comprehensive) strategic partnership, nor does it achieve the intensity of soft balancing (vis-à-vis the USA) in a particularly polarized and politicized international context.
\end{abstract}

Keywords Sino-Russian relations · Strategic partnership · Mutual support · Coronavirus · Twitter

\section{Introduction}

The outbreak of novel coronavirus pneumonia (NCP, 2019-nCoV) in China in late 2019 has created unprecedented global concern over public health and safety. While causing a global economic slowdown and nearly bringing the world to a standstill, the coronavirus has challenged the relationship between China and Russia, two global actors with an ambiguous track record of alignment and cooperation.

Maria (Mary) Papageorgiou

maria_marypapageorgiou@hotmail.com; id7645@alunos.uminho.pt

Alena Vieira

vysotskayaa@gmail.com; d4215@eeg.uminho.pt

1 Universidade do Minho, Braga, Portugal

2 Centro de Investigação em Ciência Política (CICP), Universidade do Minho, Braga, Portugal 
Almost two decades after the (SARS) outbreak, China has once more become the epicenter of a new epidemic. On 31 December, almost a month after the first incidents were reported in the city of Wuhan in November 2019 [22], the World Health Organization (WHO) was officially informed about the instances of the outbreak. This perceived delay in announcing the outbreak ignited extensive criticism from Western countries, particularly the USA, as to China's handling of the health emergency. While countries all around the world immediately extended help to China, the response of Russia, China's comprehensive strategic partner, came only later, something that has called the relationship between the parties into question and lead some analysts to affirm that it was "a little surprising that Russia was not among the first 20 countries to make donations to China during this epidemic" [74]. Moreover, Russia adopted highly restrictive measures against Chinese citizens, which were condemned by the PRC Embassy in Moscow as discriminatory [58].

To be sure, Russia's subsequent reaction has evolved within a particular context, shaped by their own health concerns, reinforced by an extensive shared border with China. However, it also evolved amidst unprecedented international polarization over the rapid spread of the virus to other countries, something that eventually urged the WHO to declare the coronavirus a global pandemic on 11 March 2020. In particular, explicit criticism of China was conveyed in US President Donald Trump's references to the "Wuhan" or "Chinese" virus, which led to direct confrontation between the two parties and the expulsion of US journalists working in China for New York Times, the Wall Street Journal, and the Washington Post [23].

Considering the unprecedented coronavirus outbreak as a stress test to the SinoRussian relationship, the present study follows an empirical goal, namely, to analyze Russian foreign policy toward China during such difficult times from a novel methodological perspective. The Sino-Russian relationship has thus far been ambivalent, allowing one to expect both a supportive and a neutral approach from Russian authorities. On the one hand, the comprehensive strategic partnership concluded between the two countries would lead one to assume that Russia might extend immediate aid and support to China, while possibly also restating its commitment to its Chinese partner and closely coordinating its own measures with Chinese authorities. This outcome becomes all the more plausible as China and Russia might be expected to draw closer together in these challenging times, in line with the idea of Sino-Russian "soft balancing" toward the USA [13, 20], aiming at establishing a common front against the US criticism directed at either of the partners. On the other hand, the SinoRussian relationship has been, as some have argued, failing to evolve beyond the notion of an "axis of convenience" [49], a relationship defined by ad-hoc cooperation that displays serious constraints to moving beyond a common-denominator cooperation despite all the existing agreements and high-level political dialog.

To ascertain Russia's position toward China in light of the developments on the coronavirus crisis and the changing international perception of China's handling of this issue, we employ content analysis of official Russian discourse between 31 December and 31 March 2020. We draw on the online publications ${ }^{1}$ issued by three official institutions: the Russian Ministry for Foreign Affairs, the President, and the

\footnotetext{
${ }^{1}$ Online publications correspond to statements, press briefings, notes regarding telephone conversations, and meeting updates published by the three Russian authorities on their official websites.
} 
Government, analyzing their official web pages (104 online publications) and Twitter accounts (260 tweets). We thus follow how Russian authorities have used Twitter and online resources to demonstrate their support for China during the coronavirus crisis.

While the consideration of online publications in the analysis of Russian foreign policy is not uncommon [48, 67, 81], systematic study of Twitter as a tool of foreign policy is less usual. This is also true of Russian relations with China, which have been analyzed from different analytical perspectives, but not as a case of "twiplomacy." The latter term, twiplomacy, ${ }^{2}$ combining "twitter" and "diplomacy," was coined in Burson and Marsteller report, published every year starting from 2011, on the annual analysis of twitter activity of influential individual actors as well as states and international organizations. Twiplomacy, which has offered space and resources to politicians to address both foreign and domestic audiences and establish direct interaction [31], has increasingly attracted the attention of scholars of foreign policy, public diplomacy, and media and communication, who have been employing methods ranging from linear regression to network analysis $[15,47,54,63,93]$, as well as content analysis $[14,26$, 71].

Studying twiplomacy is a unique methodological approach to understanding SinoRussian relations, allowing to capture the digital dimension of bilateral relations. Russian twiplomacy has been rapidly evolving, with both an active domestic and international dimension, including presentation of particular policies, promotion of cultural initiatives, and showcasing specific Russian positions, often oriented toward multilateral fora and solutions. A case in point is "Russkiy Mir" (Russian World Foundation), launched by the Russian state in 2007 to enhance Russia's soft power by promoting Russian language and culture, in an attempt that corresponded to one of the first Russia's international engagements with public digital diplomacy (@findrysskiymir, on Twitter) [76]. Some studies have started to analyze Russia's digital diplomacy as a part of their analyses of the Russian state's propaganda and strategic communication techniques, as well as of Russia's soft power projection [60, 80], often by employing network analysis or framing analysis. However, Russia's twiplomacy, and foreign policy activity in the social media in more general terms, has yet to be examined, and the present contribution aims to fill this gap.

The absence of studies on the Russian twiplomacy (including Sino-Russian relations) is all the more surprising given the recent activity on Twitter by Russian state institutions and diplomats [43, 70] who have been encouraged by Russian President Vladimir Putin to engage more actively in social media [65]. The Russian Foreign Ministry holds second place among all official Missions and ambassadorial Twitter accounts worldwide, a roster that includes 244 embassies, consulates, and trade missions. Russia's mission to NATO (@NATOmission_RU) is the second most followed mission on Twitter. Russian official bodies have been eagerly to recur to Twitter in expressing their position on the COVID-19 crisis, and to develop public digital diplomacy, as reflected in a separate twitter account established for its SPUTNIK V, COVID-19 vaccine (@sputnikvaccine). Moreover, Russia and China have been using Twitter to strengthen their relationship, for example, by retweeting each other's positions, as an expression of a shared worldview and mutual support. Cases in point are hashtags such as \#ChinaRussia70Years and

\footnotetext{
${ }^{2}$ https://twiplomacy.com/
} 
\#ChinaRussiaCrossBoderNaturalGasPipeline, widely used as a display of enhanced cooperation between the two states.

China's and Russia's use of Twitter is in line with the more general tendency of recurring to Twitter by political leaders and diplomats as a channel of communication with their counterparts [16]. A total of 280 characters also allow officials to directly interact with a global audience, including a possibility of retweeting a topic or an opinion as a form of endorsement, a common stance, or a joint effort [29]. Such rebroadcasting raises the content's visibility [9]. This has led some authors to argue that Twitter has become an indispensable instrument of foreign political activity [14], and "the most effective" foreign policy tool to promote a specific political agenda and explain a particular position [1]. The use of Twitter, therefore, holds the potential of bringing valuable insight into Russia's relationship with China, and it is hoped that the present study might provide the first outline of the digital dimension of the SinoRussian strategic partnership, which has been thus far missing from current accounts of this bilateral cooperation.

Our findings demonstrate that Russia, although late in expressing their support (their first tweet was published on 23 January), has nevertheless adopted a supportive stance toward China, proving that Sino-Russian bilateral relations are more than an "axis of convenience." Nevertheless, Russia's position remains ambivalent, as reflected in the limited references to the term "strategic partnership," and China's decreased visibility and supportive valence at a time when it is being heavily criticized by the USA, despite the context presenting a favorable opportunity to consolidate the Sino-Russian relationship as a soft balancing front toward the USA. This demonstrates the unsteady and ambiguous pattern of Sino-Russian cooperation, rather than the one of unwavering partnership emerging in the shadow of rapidly deteriorating EU-Russian relations, a tendency that has been often referred to Russia's "turn to the East," "povorot na Vostok' [36].

The paper is structured as follows. The "The Coronavirus Outbreak, World Responses, and the Russian Position" section presents the dynamics of the coronavirus outbreak, the international reaction to it, and the changing international perception of China, in the time frame defined by the first identified instances of the disease in Wuhan in December 2019 to the developments through the end of March 2020. This section also serves to divide the period under analysis into three distinct time frames defined by the intensity of the pandemic and of the criticism directed at China. The "The Sino-Russian Relationship: a Strategic Partnership Underpinned by Mutual Support or an "Axis of Convenience"?" section focuses on the Sino-Russian rapprochement and especially, on the dimension of mutual support, followed by the section presenting the methods and data used in the analysis. The empirical section corresponds to the content analysis, while the final section presents the findings and their implications for the future trajectory of Sino-Russian relations.

\section{The Coronavirus Outbreak, World Responses, and the Russian Position}

The outbreak and spread of the novel coronavirus have provoked a wide range of reactions from individual countries, which have varied over time, allowing for the identification of three distinct periods: the first, between 31 December and 1 February, 
corresponding to the identification of the epicenter of the virus in Wuhan and a generally supportive international stance toward China; the second, between 2 February and 10 March, marked by the first death outside China and the spread of the virus to other countries, generating a less favorable position toward China; and the third, between 11 March and 31 March, defined by the WHO's declaration of a global pandemic and a significant death toll around the world, as well as by China-USA bigotry over the origin of the virus and China's responsibility in handling the emergency situation.

\section{The Initial Phase: Late 2019 and January 2020}

The first incidents of coronavirus were made public by China on 31 December 2019, as the country became the epicenter of the epidemic. The Chinese government adopted a series of prevention and control measures such as home quarantine, closure of residential areas, the cancelation of all public events and large gatherings, and the suspension (and subsequent postponed resumption) of the operation of various enterprises, schools, etc. [27].

The first phase of the epidemic saw a generally supportive international stance toward China, with world leaders expressing sympathy and solidarity while simultaneously aiding China in containing the virus. According to a document published during this period of analysis with a detailed timeline and the measures taken by Chinese authorities, while speaking with German Chancellor Angela Merkel and French President Emanuel Macron by telephone, President Xi Jinping mentioned that "France supports China in actively dealing with the epidemic and is willing to enhance health cooperation with the Chinese side" [92]. Among the first countries to offer both political and material support were Iran and the United Arab Emirates [94], and even Japan, China's historical and strategic adversary, offered support and assistance. A few of China's comprehensive strategic partners, including Pakistan and Cambodia, decided not to evacuate their citizens from Wuhan while also expressing support for the measures adopted to deal with the outbreak. This was not the case of all countries; however, North Korea, China's long-standing ally, banned all travel between the two countries and closed the border with China.

Russia, meanwhile, was among the first countries to adopt restrictive measures, such as closing most points of entry along their shared 2615-mile-long border and establishing checkpoints and enforcing quarantine control in those that remained open. Furthermore, Russia suspended electronic visas for Chinese nationals, imposed restrictions on passenger railway service to China, suggested Russian universities to extend Chinese students' vacations in China until 1 March 2020, and suspended the majority of flights between the countries (except for Aeroflot flights to specific cities, including Beijing, Shanghai, Guangzhou, and Hong Kong). In addition, Russian authorities postponed the Sochi Economic Forum and Russian government representatives have threatened to deport foreigners suffering from the disease [77, 78].

Although informed by public health concerns and centered on the restrictions meant to contain the pandemic, Russia's initial stance also included showing support for 
China: Russian authorities spoke highly of the measures taken by their Chinese counterparts $^{3}$ and praised their bilateral interactions. This included a message sent by President Putin to President Xi Jinping on 31 January to express his sympathy and support. 4

\section{The Second Phase: 2 February to 10 March, 2020}

A turning point in the evolution of the coronavirus epidemic was the first death outside China, followed by the spread of the virus beyond China's borders, which led to a less favorable international perception of China. China began to experience a shortage of medical equipment as the number of cases spiked, and international aid and support continued. According to the official spokesperson of the Chinese Foreign Ministry, Hua Chynying, "the governments of 21 countries, namely, ROK, Japan, Thailand, Malaysia, Indonesia, Kazakhstan, Pakistan, Germany, Britain, France, Italy, Hungary, Belarus, Turkey, Iran, United Arab Emirates, Algeria, Egypt, Australia, New Zealand, Trinidad and Tobago, and UNICEF have donated epidemic prevention and control supplies to China. Friends in many countries have also offered us support by various means." 5

Russia was not mentioned in this briefing. By late February, the "weeks of gradually escalating restrictions" [84], including the banned entry of all Chinese citizens and the alleged instruction for public transport drivers in Moscow to call police if they saw Chinese passengers, had led Chinese authorities to send a letter to the PRC embassy of Moscow stating that "this kind of special monitoring of Chinese citizens in public transport in Moscow doesn't exist in any country, not even in the US or other Western nations" and emphasizing that such treatment "will harm the good atmosphere for developing Chinese-Russian relations" [58, 84]. Thus, while vocally supportive of China, Russian authorities also "revealed a certain level of distrust within Russian government and society toward China" [24].

A factor enabling the subsequent rapprochement and normalization of the relationship was the provision of medical supplies by Russian authorities on 9 February, as well as the dispatch of a team of experts to China [78, 84]. Eventually, both parties reiterated the importance of their good relationship, including between the two leaders. While thanking Russian President Putin for his phone call to President Xi, the Chinese Minister for Foreign Affairs, Wang Yi, mentioned that this initiative "reflects the strong mutual trust between the two Presidents and the high level of the comprehensive strategic partnership of coordination for the new era between China and Russia."6

\footnotetext{
${ }^{3}$ MFA webpage, Press release on Foreign Minister Sergey Lavrov's telephone conversation with the Foreign Minister of the People's Republic of China Wang Yi, 6 January 2020

${ }^{4}$ Kremlin webpage, President sent message to Xi Jinping to express sympathy and support to coronavirus victims, 31 January 2020

${ }^{5}$ Foreign Ministry Spokesperson Hua Chunying's Daily Briefing Online on 5 February, 2020 https://www. fmprc.gov.cn/mfa_eng/xwfw_665399/s2510_665401/2511_665403/t1740929.shtml

${ }^{6}$ State Councilor and Foreign Minister Wang Yi Had a Phone Call with Russian Foreign Minister Sergei Lavrov, 2 February, 2020 https:/www.fmprc.gov.cn/mfa_eng/zxxx_662805/t1739124.shtml
} 


\section{The Global Pandemic: 11 to 31 March}

After the WHO announcement on 11 March 2020 that the novel coronavirus had reached pandemic status, and as its epicenter shifted to Europe, including Italy, Spain, and Switzerland, accusations against China began to be voiced. In addition to general accusations of disinformation and propaganda, ${ }^{7}$ US President Donald Trump repeatedly referred to the coronavirus as the "Chinese virus," such as when he stated that "The United States will be powerfully supporting those industries, like airlines and others, that are particularly affected by the Chinese virus. We will be stronger than ever before," done a very good job from the beginning, including my very early decision to close the 'borders' from China - against the wishes of almost all. Many lives were saved." ${ }^{\prime \prime}$ In the same vein, US Secretary of State Michael Pompeo has referred to the coronavirus as the "Wuhan virus." Both expressions were condemned by the Chinese Foreign Ministry, ${ }^{10}$ which tweeted in response: "US officials said they offered \$100 million to China and other countries. We thank the American people for their kind help. But as a matter of fact, we haven't received \$1 from the US government. By the way, has the US paid its dues to WHO?" 11 Tension between the two countries has been mounting, triggering comments on the emergence of a "New Cold War" between the USA and China [28]. This tension between the USA and China in the third period under analysis held the potential of a unique context for Russia's response, once again testing the extent of the support and commitment to its partner.

\section{The Sino-Russian Relationship: a Strategic Partnership Underpinned by Mutual Support or an "Axis of Convenience"?}

Sino-Russian rapprochement dates back to the 1980s, when Mikhail Gorbachev and Deng Xiaoping issued (the second) Joint Statement, which allowed the Sino-Russian partnership to take its initial shape. While Presidents Jiang Zemin and Boris Yeltsin declared their commitment to building "a constructive partnership featuring good neighborliness, friendship and mutually beneficial cooperation” in 1994, it took another 2 years to adopt the strategic partnership of equality, mutual confidence, and mutual coordination in the twenty-first century, while the subsequent Treaty for Good Neighborliness, Friendship, and Cooperation was only signed in 2001. In this historic treaty, Moscow and Beijing agreed to develop long-term relations of friendship and equal partnership and mutually beneficial cooperation in trade, military, energy, and other fields [12].

\footnotetext{
${ }^{7}$ Briefing on Disinformation and Propaganda Related to COVID-19, Lea Gabrielle, Special Envoy and Coordinator of the Global Engagement Center,27 March 2020 https:/www.state.gov/briefing-with-specialenvoy-lea-gabrielle-global-engagement-center-on-disinformation-and-propaganda-related-to-covid-19/

$8 @$ realDonaldTrump, 17 March 2020

9 @ realDonaldTrump, 18 March 2020

${ }^{10}$ Foreign Ministry Spokesperson Geng Shuang's Regular Press Conference on 20 March 2020, https://www. fmprc.gov.cn/mfa_eng/xwfw_665399/s2510_665401/t1758992.shtml

${ }^{11}$ Hua Chunying @ SpokespersonCHN, 20 March 2020
} 
Eventually, by the end of the second decade of the twenty-first century, the two countries managed not only to settle their border disputes but also to identify similar worldviews, expressed in their 1997 joint statement Declaration on a Multipolar World and the Establishment of a New International Order. ${ }^{12}$ The comprehensive strategic partnership (of coordination for a new era) has also been recognized as indicative of their shared worldviews, which often stand in opposition to Western values and norms [50]. Moreover, the good interpersonal relationship between presidents Vladimir Putin and Xi Jinping, nowadays considered to be "warmer than ever" [7, 46] or "the best ever" [44], has allowed several analysts to advance the argument that the Sino-Russian relationship is an alliance in the making $[2,41]$.

\section{The Sino-Russian Relationship as a Relationship of Mutual Support}

The existence of a comprehensive strategic partnership would lead one to expect Russia to adopt a continuously supportive stance toward China in the context of the coronavirus, beginning immediately after the announcement of the outbreak and reinforcing this stance in the third phase when China became the subject of criticism, most notably from the USA.

While mutual support is crucial for maintaining and strengthening any strategic partnership, China and Russia have been especially keen to emphasize that their relationship is built on mutual support, reflected in such statements as, "In the new stage, China and Russia will provide stronger mutual support, open wider to each other, and take cooperation to a greater depth." ${ }^{.13}$ Moreover, and contrary to the early stages of China-Russian cooperation [18], the parties have been considered to gradually create expectations of reciprocity and behavioral manifestations of trust [95].

Russia's assumption of a supportive position in the context of the coronavirus would be also in line with the instances of Russia's diplomatic support toward China including calling against the Taiwan, Xinjiang, and Tibet separatist movements [49]. As for China, manifestations of support range from the diplomatic support shown during the Chechnya wars (1994-2000) to the presence of the Chinese leader at the Winter Olympics in Sochi (2014) and at the Victory Day parade (2015). China has also assumed a position that is openly contrary to that of other countries, as in the Skripal case since 2018, by not only abstaining from expelling Russian diplomats but also insisting, at the UN Security Council, on an impartial investigation based on the norms of international law, further adding that Russia and Britain "can handle the issue through the appropriate channels" (UN Security Council meeting 8203, 2018). ${ }^{14}$

One could also expect to see reinforced Russian support for China during the third period under analysis (11 to $31 \mathrm{March}$ ) when China became the subject of increased criticism, especially from the USA, given that this particular context created an

\footnotetext{
12 Joint Statement of The People's Republic of China and the Russian Federation on Major International Issues Beijing, 23 May 2008, https://www.fmprc.gov.cn/mfa eng/wjdt 665385/2649 665393/t465821.shtml ${ }^{13}$ Speech given by H.E. Li Keqiang, Premier of the State Council of the People's Republic of China, at the Third Moscow International Forum for Innovative Development, 14 October $2014 \mathrm{https}$ :/www.fmprc.gov.cn/ mfa_eng/wjb_663304/zzjg_663340/dozys_664276/gjlb_664280/3220_664352/3223_664358/t1202857.shtml

14 Overview of Security Council Meeting Records

This was a meeting convened regarding the use of a nerve agent in Salisbury, https://www. securitycouncilreport.org/un-documents/document/spv8203.php
} 
opportunity for Russia and China to establish a common front against the US-led world order, in an act of "soft balancing." The latter corresponds to "tacit balancing short of formal alliances," manifested in the "ententes or limited security understandings with one another to balance a potentially threatening state or a rising power" [62, p.3]. Soft balancing furthermore involves a "conscious coordination of diplomatic action in order to obtain outcomes contrary to US preferences, outcomes that could not be gained if the balancers did not give each other some degree of mutual support" [86, p.126].

Indeed, it can be argued that the USA has played a prominent role in the SinoRussian relationship. Both countries have expressed their dissatisfaction with US unilateral actions, including the war in Iraq [3], as well as with what has been viewed as an aspiration to diminish the role of the United Nations (UN) through the NATO Eastward enlargement and the use of humanitarian considerations to interfere in affairs of sovereign states. They have further criticized the US' approach towards international treaties and shown increased dissatisfaction with the imposed US sanctions following the annexation of Crimea and the US-China trade war [87]. More recently, the two countries have expressed their converging views on spearheading an Internet sovereignty agenda to oppose US technological hegemony [10] and have also established a Media Forum to further strengthen their digital media cooperation.

Furthermore, strategic partnerships have been identified as "anchors of soft balancing" $[20,83]$; several authors have credited the Sino-Russian strategic partnership with having "soft balancing" potential, both implicitly, defining it as a response to the uncertainty in the international environment and explicitly, noting that "the main engines driving the strategic partnership between Russia and China are external factors arising from the international environment and its key player, the United States" [66, p. 9].

\section{The Chinese-Russian Relationship as an (Enduring) "Axis of Convenience"}

Another view on Sino-Russian cooperation is that this relationship, in spite of all the agreements and high-level political dialog, has failed to evolve beyond a mere "axis of convenience" [49]. China and Russia have accordingly developed ad hoc cooperation, displaying serious constraints to moving beyond such a common-denominator, flexible, and opportunistic relationship driven primarily by national interest [49]. Given this cooperation record and the existence of a common border, one might expect Russia to focus on its domestic (health) problems and defend them on the international scene (if necessary, by cooperating with the West and the USA, for instance, with lifting of sanctions in view) rather than support China.

Russia's neutral rather than actively supportive position toward China is also in line with the previous track record of Chinese-Russian relations. This includes such critical events as Russia's lack of openly supporting China's South China Sea policy [40, 42]; or China's absent support to the annexation of Crimea, or of the independence of Abkhazia and South Ossetia [34], in line with China's traditional "maneuvering," i.e., assuming a neutral stance in most international disputes [45]. These positions have been interpreted in the following way: while "both states' elites do not have to be afraid of a 'stab in the back' in the face of Western pressure", they also "do not receive active support for their actions or claims" [35]. 
A more recent instance of Russian distancing from China is the US-China trade war. Russia has referred to it as falling beyond the scope of its interests, with the Russian Presidential spokesperson stating that "Washington and Beijing can wage those trade wars, but it is not our war. Russia is interested in building independent relations both with China and with the US." [79].

The Sino-Russian relationship has also been considered "competitive" at the regional level $[17,33,38,40]$, for instance, where both have produced a "clash of influence" in Central Asia. Mutual distrust is considered one of the issues barring further strengthening of their relationship, due not only to the divergence of geopolitical interests in Central Asia but also to their history of mistrust [11]. It can therefore be assumed that this lack of trust might prevent Russia from articulating an actively supportive position toward China regarding the coronavirus.

\section{Operationalization, Method, and Data}

The research technique chosen to examine Russia's approach in this article is a quantitative content analysis of tweets, which are shorter and more targeted, and "official statements" published on institutional websites, which represent a more formal form of communication. This is a case study, wherein the evaluated data serve as trend indicators for the present analysis, with no intention of generalizing the findings in a statistical manner. However, the analysis does provide insight into the support that exists between the two partners, the depth of their partnership, and the prospects for "soft balancing" behavior.

Content analysis is a technique for both collecting and analyzing the content of a text, allowing to describe or present a certain subject, and identify the trends occurring to this subject over time [88].

The present study of Russian foreign policy discourse employs computer-assisted content analysis of selected online publications and tweets using WordStat [91]. It is aimed firstly at identifying the visibility and, secondly, the valence of the references to China. Both categories have already been used to discern the importance and the tone or attitude of a certain topic and are useful for achieving our objective of ascertaining Russia's (supportive) stance toward China.

Manheim and Albritton [53] define visibility as "the amount of media coverage" that a certain word or term receives. In foreign policy research, attention directed toward another country implies that that actor is prioritized on the policy making agenda. The authors [53] refer to visibility as an important dimension of salience, measured by the total amount of coverage a country receives from the respective source. Accordingly, visibility in this analysis corresponds to the amount of coverage the term "China" received in association with the coronavirus outbreak. It is examined through a frequency count of the words "China," "Chinese," and "PRC" appearing in official statements published on institutional websites and tweets. This frequency of mentions helps identify the occurrence and prominence of a topic within a specific text $[68,75]$. In this study, the frequency of mentions reflects the importance Russia attributes to China in their (foreign policy) agenda and "twigenda."

Valence, corresponding to the "degree to which the content that is available reflects either favorably or unfavorably on the country" [53, p. 645], refers to the tone used to 
present and describe a certain issue, while also indicating the attitude expressed toward it $[6,19]$. In this paper, it is categorized along the dimension of mutual support, which is seen as indispensable for countries striving to achieve a closer, comprehensive, and solid strategic partnership. Accordingly, we distinguish between two valence categories: "supportive" and "not supportive."

As such, the visibility of one country in another's Twitter coverage is indicative of their level of bilateral relations. Most importantly, during a period of crisis such as the coronavirus pandemic, the visibility and tone toward China adopted by the Russian authorities on Twitter, particularly since it occurs in real time, can provide insight as to the level of support between the two countries.

Against this background, two of our hypotheses, the first addressing the nature of the Sino-Russian relationship and the second the potential for "soft balancing," are defined as follows:

\section{H1: Strategic Partnership underpinned by mutual support:}

Russia's foreign policy discourse will tend to display a relatively high level of visibility and supportive valence for "China" in the context of the coronavirus, with a hypothesized value for both visibility and supportive valence coming close to $50 \%$.

According to this hypothesis, we would also expect Russia to actively endorse China's position via mentions and hashtags, thereby indicating a common stance or a joint effort, and to retweet Chinese statements to ascribe importance to "a given issue on the political agenda" $[73,90]$.

This is contrary to the relationship underpinned by an "axis of convenience," suggesting a low level of visibility and neutral valence in Russia's discourse toward China in the context of the coronavirus. Huang and Wang [30] demonstrate reasons to expect such an approach, as well: their study on the Chinese government's Twitter network from 2014 to 2018 showed that Russia is not among the most Frequently Mentioned Users, nor in the Top 20 Hashtags, unlike the EU, India, and Pakistan. The study concluded that China's Twitter network centers primarily on its closest friends, a group of countries that does not include Russia, China's comprehensive strategic partner.

\section{H2: Strategic Partnership as soft balancing:}

The greater the intensity of US criticism of China's measures to fight coronavirus (as it has been in the third period), the greater China's visibility and more supportive its valence in Russia's foreign policy discourse.

According to this hypothesis, China is also expected to receive more intensive coverage in Russian political discourse during the third period, with a (more) supportive stance being expressed by all channels of the Russian authorities. Additionally, high visibility and a supportive valence in the third period indicate that Russia perceives its relationship with China as a priority in its foreign policy, both at the global and regional level. 
We thus expect not only "China" but also "strategic partnership" to display visibility in Russia’s foreign policy discourse.

\section{Data}

The data were collected from the English version of the official web pages of the Russian Government (government.ru), Kremlin (kremlin.ru), and the Ministry of Foreign Affairs (mid.ru) and their respective Twitter accounts: @GovernmentRF, @KremlinRussia_E, @mfa_russia. By using the search function on the webpages and the advanced search in Twitter with the keywords "coronavirus" or "COVID19," a series of data $(n=364)$ were downloaded. Of these, 104 online publications were collected from the three main channels. Additionally, 260 tweets were mined from the same official channels.

\section{Unit of Analysis}

This study relies on two units of analysis: tweets and online publications on the official websites of the three institutions, an approach that allows for the triangulation of data. The three accounts were selected for being the most followed accounts in Russia and for having established a foreign policy network (by following accounts of their counterparts from other countries) [82]. While long-standing Russian President Vladimir Putin does not have a personal twitter account, he is represented on Twitter by the official Kremlin page inaugurated in October 2010. Out of the three Twitter accounts, the Russian Ministry for Foreign Affairs (MFA) has the most active representation, while the Kremlin is the most followed.

While 280 characters force officials to compact their messages, they have considerable potential to reach and influence a global audience. The option to use Twitter as a form of endorsement, allowing individuals to rebroadcast content while also using mentions and hashtags [29, 69], has led to the acknowledgment of Twitter as a platform for the spread of (often contagious) information phenomena [5, 37]. In their turn, statements on official webpages lack not only Twitter's interactive dimension, they are also less frequent than tweets. However, they allow for a more detailed representation of an issue and are composed in a more formal tone, aiming to inform rather than influence their audience.

\section{Coding Procedures}

In this study, visibility is defined and measured as the frequency of "China" in the overall coverage of coronavirus in the collected online publications and tweets. The frequency of mentions of a certain issue is used to identify the occurrence and prominence of this topic in a specific text $[68,75]$. The coding procedure for frequency is based on a word count completed by the software. Ultimately, 34 documents out of 104 and 41 tweets out of 260 contained references to China.

For valence, we opted to take a built-up, dictionary-based approach. This involved formulating a dictionary list for two categories ("supportive" and "non-supportive") based on word phrases identified as a result of combining a frequency count and clustering analysis, following WordStat's standard process. The ratio (of positive 
messages to overall messages mentioning "China") was calculated based on a proportional weighting scheme for each category assigned to each tweet or document referring to China during the respective period.

In the case of the longer and more detailed online documents, we have considered those containing more than two references of the predefined dictionary terms appearing in association with China to be of the supportive valence. These terms include "support," "agree," "congratulate," "partnership," "friends," "cooperation," "coordination," and "assistance," in contrast to a neutral or non-supportive stance expressed by terms such as "criticism," "delay," "deny," and "withhold."

Lastly, as an additional step, the study employs visibility analysis via keyword search $^{15}$ of the term "strategic partnership" in Russian foreign policy discourse. During a time of crisis, the endorsement of cooperation and (a strategic) partnership is particularly important.

To ensure intercoder reliability, both authors analyzed the data. The use of Krippendorff's alpha was calculated to assess intercoder reliability with the online program ReCal2. A score of ( $\alpha=0.90)$ was achieved for the coding of online publications and the tweets. A preliminary cross-check of the documents with the Russian version of the material was also performed before the coding analysis.

\section{Results}

\section{Visibility}

Firstly, the dates of the first references to China in regard to the coronavirus were identified: the first online publication referring to China was issued on 23 January by the MFA and the first tweet was published on 29 January by the Government. These statements, issued almost 1 month after China began to deal with the coronavirus outbreak, confirm that Russia's response to its comprehensive strategic partner indeed came late.

The first category, visibility, aims to identify how much attention is paid to "China" in the whole of the coronavirus coverage of official Russian foreign policy discourse (see Table 1)..

The findings in Russia's online publications on institutional webpages indicate that China had high visibility in the first period with a total of 8 documents out of 9 , corresponding to $89 \%$ coverage. This percentage decreased to $67 \%$ in the second period and, in an even more substantial decrease, to $19 \%$ in the third period. Overall, the visibility of China in online publications corresponds to $35 \%$.

On Twitter, China's visibility in coronavirus coverage is even lower (amounting to $12 \%$ ), which can be explained by a diversification of topics related to coronavirus in the second and third time periods (such as topics relating to economic implications, for example) as well as the inherent differences between the first (initial response to the outbreak), versus the second (epidemic) and third (pandemic) period, and the corresponding retweets by other official Russian accounts. The results indicate that China

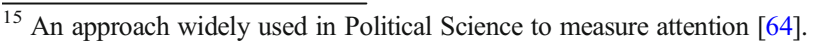


Table 1 Visibility of "China" in Russia's tweets and online publications on institutional webpages

\begin{tabular}{llllllll}
\hline Period & \multicolumn{2}{l}{ Twitter } & & & \multicolumn{2}{l}{ Online publications } \\
\cline { 2 - 4 } \cline { 5 - 7 } & Coronavirus & China & $\%$ & & Coronavirus & China & $\%$ \\
\hline 31 Dec-01 Feb & 36 & 13 & $36 \%$ & 9 & 8 & $89 \%$ \\
02 Feb-10 Mar & 42 & 9 & $21 \%$ & 21 & 14 & $67 \%$ \\
11 Mar-31 Mar & 182 & 9 & $5 \%$ & 74 & 14 & $19 \%$ \\
Total & 260 & 31 & $12 \%$ & 104 & 36 & $35 \%$ \\
\hline
\end{tabular}

received $36 \%$ visibility in coronavirus coverage during the first period, $21 \%$ in the second, and $5 \%$ in the third.

China's visibility in coronavirus coverage corresponded to 31 instances on Twitter (tweets) and 36 in online publications, corresponding to a rather modest total of $12 \%$ and $35 \%$, respectively. Moreover, in the third period, after the coronavirus had been classified as a pandemic and China began to receive severe criticism for its handling of it, China's visibility in Russian discourse decreased critically, both on Twitter and in online publications.

\section{Valence}

As for valence, the analysis allows Russia's position to be classified as underpinned by a generally supportive tone toward China. A positive stance, expressed by a significant number of supportive tweets and statements (in addition to a low number of explicitly negative/critical statements), is an indicator of support for a country (Table 2) [56].

The data on valence for Twitter show that Russia's supportive valence toward China corresponds to $31 \%$ in the first period, to $44 \%$ in the second, and $22 \%$ in the third, with an average value of $31 \%$. The other unit of analysis, online publications/statements, demonstrated a higher supportive valence than Twitter, with $75 \%$ in the first period, $57 \%$ in the second, and $43 \%$ in the third, corresponding to an average of $53 \%$.

Table 2 Valence of "China" in Russia's Twitter and online publications

\begin{tabular}{|c|c|c|c|c|c|c|}
\hline \multicolumn{4}{|l|}{ Twitter } & \multicolumn{3}{|c|}{ Online publications } \\
\hline Period & China & Supportive & Non-supportive & China & Supportive & Non-supportive \\
\hline $31 \mathrm{Dec}-01 \mathrm{Feb}$ & 13 & $31 \%$ & $0 \%$ & 8 & $75 \%$ & $0 \%$ \\
\hline 02 Feb-10 Mar & 9 & $44 \%$ & $11 \%$ & 14 & $57 \%$ & $0 \%$ \\
\hline 11 Mar-31 Mar & 9 & $22 \%$ & $0 \%$ & 14 & $43 \%$ & $0 \%$ \\
\hline Total & 31 & $31 \%$ & $3 \%$ & 36 & $53 \%$ & $0 \%$ \\
\hline
\end{tabular}

The second and the fifth columns are the number in which China is referred in Twitter and online publications, respectively

Supportive refers to the percentage of times in which Tweets and publications are positive-toned toward China Non-supportive refers to the percentage of times in which Tweets and online publications are negative-toned toward China 
Additionally, there was a slight decrease in supportive valence on both Twitter and in online publications, from 44 to $22 \%$ (Twitter) and from 57 to $43 \%$ in the second and third period, respectively.

The tweets underpinned by a supportive valence tend to refer to specific bilateral arrangements and measures between the countries, such as airline cooperation ("Upon an agreement with China, flights of four Chinese airlines to Moscow will remain in operation" "16) and cooperation in general (\#Russia, in close cooperation with its Chinese partners, is currently taking the necessary measures to prevent the spread of the coronavirus in Russia. \#Coronavirus \#China ${ }^{17}$ ). Markers of a clear supportive stance, both toward China in general and toward China's handling of the coronavirus in particular, include, for instance, a note that President Putin had sent "a message to Xi Jinping to express sympathy and support to coronavirus victims," ${ }^{8}$ as well as expressing "our solidarity with the \#Chinese people and leadership in relation to the efforts that are being made successfully and transparently to thwart the \#coronavirus epidemic. \#Russia greatly appreciates this." 19

Both leaders have expressed their mutual support and reiterated the importance of their close cooperation on the matter in a series of telephone calls, reinforcing the idea of a good interpersonal relationship between the two leaders as a backbone of their strategic partnership [7].

Moreover, Russian authorities have expressed their support for China alongside the other four BRICS countries, as reflected in tweets such as "The \#BRICS countries support the firm commitment and decisive efforts of the \#Chinese Government to combat the Novel Coronavirus Pneumonia Epidemic."20

As for the (explicitly) non-supportive valence, only one instance of this was identified, corresponding to a Government tweet on 3 February and accounting for $11 \%$. It maintains that "Our experts are working on it. As the Chinese side has not provided us with any data on the vaccine and the strain, we are relying on our available sources." ${ }^{21}$ Importantly, the tweet was made during the second period, 1 day after the first deaths were registered outside China and in the midst of growing criticism toward China regarding how promptly it informed the WHO of the coronavirus outbreak and its prevention of allowing scientists from other countries to access and evaluate the available data [59].

Nevertheless, the analysis of the valence of both tweets and online publications indicates that Russia has been supportive of China. Indeed, Russia even came to praise China's measures for fighting the coronavirus, highlighted the importance of cooperation, and clearly expressed support "The Russian side spoke highly of the measures taken by China in fighting the spread of the illness caused by the coronavirus. The discussion also focused on issues of Russia-China interaction in this area."22

\footnotetext{
${ }^{16} @$ KremlinRussia E, 31 January 2020

17 @mfa_russia,12 February 2020

$18 @$ GovernmentRF,31 January 2020

$19 @$ mfa russia 17 February 2020

$20 @$ mfa russia, 11 February 2020

21 @ GovernmentRF, 3 February 2020

${ }^{22}$ MFA webpage, Press release on Foreign Minister Sergey Lavrov's telephone conversation with Foreign Minister of the People's Republic of China Wang Yi, 1 February 2020
} 
The idea of support extends to the notion of common efforts and cooperation, such as when "Vladimir Putin confirmed his readiness to provide the necessary assistance to the friendly Chinese people and informed Xi Jinping that the relevant Russian authorities are set to cooperate as closely as possible with their counterparts in China to ward off this shared threat as soon as possible." ${ }^{23}$

Both the MFA and the Kremlin also issued statements in recognition of China's responsible stance toward fighting the coronavirus, such as regarding the sensitive issue of revealing the statistics of the infected and dead: "As you know, the People's Republic of China publishes official data, which I will not repeat here. We fully support China in its struggle against this epidemic." 24

In addition, the Russian MFA retweeted a post by the spokesperson for the Chinese Ministry for Foreign Affairs, Lijian Zhao, on 9 February with a short video and the caption "Thousands of Russians chanted 'come on, China!' in Chinese, wishing China an early victory over the epidemic. Thank you, Russia!"25 This is an important finding since it is Russia's only retweet of any other foreign official during the whole period under analysis.

\section{Visibility of "Strategic Partnership"}

A final analytical step in this study aimed to establish the frequency count of the term "(comprehensive) strategic partnership" (as well as "partners" and "friends"), in line with the terms both parties have used to describe their relationship. However, the results obtained from the data collected for the present study indicate that there were few references to these terms during the time period under analysis (Table 3).

In fact, the Kremlin has used the term "comprehensive strategic partnership" only once, during the presentation of foreign ambassadors' letters of credence to President Putin, when relations with China were referred to as being "at an unprecedentedly high level. In fact, this is a comprehensive strategic partnership". ${ }^{26}$ In published statements regarding the telephone conversations between Putin and Xi Jinping, the Kremlin has twice referred to their friendly relations: "In addition, the leaders exchanged opinions on a number of other aspects of promoting friendly Russian-Chinese relations", ${ }^{27}$ while also stating that "We are ready to render help and every kind of assistance to the friendly Chinese people." 28

In the documents collected from the Ministry of Foreign Affairs, there are just two references to either "strategic partnership" or "partners" referring to China: "At present, in close cooperation with our Chinese partners, Russia is taking all the necessary measures to prevent the spread of the coronavirus here," 29 and "The parties discussed the current international coronavirus situation and praised the bilateral cooperation in

\footnotetext{
${ }^{23}$ Kremlin webpage, President Putin sent a message to President Xi Jinping to express sympathy and support for coronavirus victims, 31 January 2020

${ }^{24}$ MFA webpage, Briefing by Foreign Ministry Spokesperson Maria Zakharova, Moscow, 27 February 2020

${ }^{25}$ Lijian Zhao 赵立坚 @ zlj517, 9 February 2020

${ }^{26}$ MFA webpage, Press release on Foreign Minister Sergey Lavrov's telephone conversation with China's Minister of Foreign Affairs Wang Yi, 18 March 2020

${ }^{27}$ Kremlin webpage, Telephone conversation with President of China Xi Jinping, 19 March 2020

${ }^{28}$ Kremlin webpage, Presentation of foreign ambassadors' letters of credence, 5 February 2020

${ }^{29}$ MFA webpage, Briefing by Foreign Ministry Spokesperson Maria Zakharova, 12 February 2020
} 
Table 3 Visibility of "Strategic Partnership" in Russia's official discourse (keyword search)

\begin{tabular}{llllll}
\hline Official channels & Total ref & Type & SP ref. & Total China ref. & Ratio SP/T China \\
\hline Government & 0 & Documents & 0 & 22 & $0 \%$ \\
\multirow{2}{*}{ Kremlin } & \multirow{2}{*}{1} & Twitter & 0 & 10 & $0 \%$ \\
\multirow{2}{*}{ MFA } & Documents & 1 & 26 & $3.8 \%$ \\
& \multirow{2}{*}{6} & Twitter & 0 & 5 & $0 \%$ \\
& & Documents & 3 & 47 & $6.3 \%$ \\
\hline
\end{tabular}

countering the pandemic in the spirit of the Russian-Chinese strategic partnership." 30 Statements on the official Government webpage include neither of these terms.

Finally, the present analysis also aimed to identify the most frequently used hashtags in tweets referring to China, two of which were \#China and \#RussiaChina. While the most popular hashtags overall in the whole of the coronavirus coverage were \#Russiahelps, \#fromRussiawithlove, \#fighting coronavirus, and \#westandtogether, frequently used by the MFA, none of these contained references to China.

\section{Discussion and Conclusions}

Aiming to ascertain how Russian representatives have used Twitter and online sources to express their support toward China during the coronavirus crisis, the present study has carried out a threefold content analysis of Russia's official discourse (examining the visibility of China; the supportive valence of "China," and the visibility of the SinoRussian "strategic partnership"), allowing us to draw the following conclusions.

The first hypothesis assumed a relatively high visibility and supportive valence toward China in Russia's discourse, corresponding to a strong bilateral relationship, and can be partially confirmed. Russia's position is often supportive, reflected in China's visibility of $89 \%$ (online publications) and $36 \%$ (Twitter) in the first period and $67 \%$ (online publications) and $21 \%$ (Twitter) in the second period. The supportive valence of China in Russia's discourse corresponds to an average value of 53\% (online publications). There is only one instance of negative valence, and Russia's supportive stance on the sensitive issue of the count of the infected and dead in China (during the first period) corroborates the argument of a strong Sino-Russian relationship. Its more recent manifestations are joint actions and cooperation, such as the ones aimed at providing and delivering humanitarian assistance (over 20 tons of supplies) to Moldova in April 2020 (Russian MFA tweeting “\#Russia helps deliver medical equipment from \#China to \#Moldova to save lives and fight \#COVID19 - AN-124 Ruslan brings 40 tons of aid to Kishinev \#WeStandTogether" ${ }^{\prime 1}$ ) or the common stance taken against the

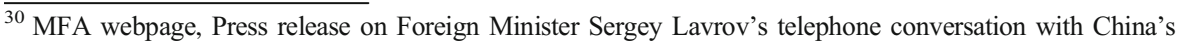
Minister of Foreign Affairs, Wang Yi, 18 March 2020

$31 @$ mfa_russia, 20 April 2020
} 
politicization of the pandemic in April 2020. ${ }^{32}$ Both countries can be thus viewed as having moved beyond the opportunistic "axis of convenience," which would be defined by a growing asymmetry of their positions and interests [49].

This is not to say, however, that the parties have reached a consolidated strategic partnership underpinned by continuous and unwavering mutual support. The average results of China's visibility and supportive valence do not always match the hypothesized value of 50\% commensurate with a consolidated (comprehensive) strategic partnership (of coordination in a new era). China's average visibility is $12 \%$ (Twitter), and 35\% (online publications), while the average value of China's supportive valence on Twitter is $31 \%$. China's supportive valence in online publications, corresponding to an average of 53\%, is the only one that allows the first hypothesis to be confirmed. Moreover, China's visibility in Russia's discourse decreases over time, while the visibility of the Sino-Russian "strategic partnership" is surprisingly low. Russia's alignment with China's official statements remains limited. This is in addition to Russia's rather delayed reaction to the coronavirus outbreak in China, China's criticism of Russia's initial measures, and China's limited communication regarding the epidemic vis-á-vis Russia and accusations of post-Wuhan instances of coronavirus being "imported" into China by travelers from Russia in April ${ }^{33}$ igniting "lingering mistrust at both the general public and senior official levels" [24]. These incidents were primarily referred to the increased instances of infection in the Heilongjiang region by the Chinese returning from Russia (Pogranichniy). The Russian government was heavily criticized for its poor performance in containing COVID-19 in Chinese social media; the hashtag "Heilongjiang reported 20 imported cases from Russia yesterday" was viewed 93 million times on Weibo. ${ }^{34}$ In response, the Russian Presidential Press Secretary Dmitry Peskov directed his discontent at the Chinese media and not the government while emphasizing that Russia would abstain from criticism as a basis of its international approach to COVID-19 and rather prefer to see international actors joining forces in the fight against the virus. This statement sought to downplay any friction in Sino-Russian relations, an approach that one can also identify in the position of the Chinese officials, for instance in the PRC Foreign Ministry Spokesperson Zhao Lijian urging the Russian government to provide guarantees for the well-being of infected Chinese citizens while stressed the need that all Chinese citizens should "comply with Russia's pandemic prevention regulations" (FMPRC, 2020). ${ }^{35}$

The results do not allow for the confirmation of the second hypothesis, which stipulated an increase of both visibility and valence in the third period under analysis, as well as an increase in visibility of "strategic partnership." China's visibility in Russia's discourse and its supportive valence both display a decrease, as does the visibility of "strategic partnership," despite receiving clear and open criticism from the USA during the third period, with the USA accusing both China and Russia of

\footnotetext{
$32 @$ mfa_russia, 7 April "Statement of the \#Group77 \& China on combating \#COVID19 that expresses the position of the majority of UN Member-States goes in line with rejection of politicized approaches and in favor of unifying agenda for intnl interaction that Russia fully shares."

${ }^{33}$ China tackles coronavirus cluster brought from Russia, 9 April https://www.aljazeera.com/news/2020/4/9/ china-tackles-coronavirus-cluster-brought-from-russia

$34 \mathrm{https}$ ///eurasianet.org/infodemic-infects-chinese-russian-relations

${ }^{35}$ https://www.fmprc.gov.cn/mfa_eng/xwfw_665399/s2510_665401/t1767935.shtml
} 
disinformation and propaganda. ${ }^{36}$ Thus, a unique opportunity for China and Russia to move toward "soft balancing" and forge a common front against US criticism remains ignored, in spite of their alleged aspirations to contest any tendency toward unipolarity and the predominance of the "historical West" which is the opposite of a "more just and democratic polycentric world order" (Foreign Minister Lavrov, 2017). ${ }^{37}$ The absence of a coordinated stance or respective joint initiatives calls into question some of the existing ideas on the Sino-Russian relationship as an "alliance in the making" or an actual alliance [2, 41, 52], as well as the argument that US unilateralism could transform (Sino-Russian) soft balancing by "hardening" the Sino-Russian relationship into a formal alliance, eventually leading to hard balancing [61]. Thus, assumptions that Western pressure should deepen the Sino-Russian partnership are proven wrong, thereby indicating that the Sino-Russian relationship continues to not be one of a mere reaction to the USA's power and policies [35]. These findings are also relevant to the argument of Russia's post-2014 "high profile turn to the East" [39], especially in light of the most recent Russia-US rapprochement in April 2020, which saw Russia providing the USA with medical gear and equipment, frequent telephone calls between presidents regarding the coronavirus ${ }^{38}$ or oil prices, ${ }^{39}$ and a Joint Statement on Commemorating the 75th Anniversary of the Meeting on the Elbe (White House, 2020), ${ }^{40}$ which can be considered unprecedented for US-Russia relations since 2009 and their "reset" (White House, 2009). ${ }^{41}$ Thus, even though Russia criticizes the USA, e.g., the decision to suspend their financing of the $\mathrm{WHO}^{42}$ or Washington's attempts to lobby pharmaceutical companies' interests in Europe, ${ }^{43}$ Russia's position resembles a dual track approach rather than one of Sino-Russian "soft balancing." This once again confirms the already existing argument that "the relationship between the United States, Russia, and China has a 'competitive, triangular aspect to it, with each side adapting hedging strategies" [8, p.11]. In this regard, future research of Sino-Russian relations could productively employ constructivist (including role theory) perspectives [57], as well as sociological institutionalist [55] and social identity theory [85] approaches, given their attention to both the formal and informal dimension of bilateral relations, as well as to the critically important issue of mutual trust [41, 51, 72, 89]. Nevertheless, the present analysis did discern an instance of an incipient "soft balancing" approach in Russia's discursive alignment with the BRICSs, which is in line with some accounts of BRICS [21, 32]. This "BRICSification" of "soft balancing" once again raises a

\footnotetext{
$\overline{36}$ Briefing on Disinformation and Propaganda Related to COVID-19 (footnote 6)

${ }^{37}$ Foreign Minister Sergey Lavrov's remarks and replies to media questions during the Government Hour in the Federation Council of the Federal Assembly of the Russian Federation, Moscow, December 15, 2017, https:/www.mid.ru/en/press_service/minister_speeches/asset_publisher/7OvQR5KJWVmR/content/id/ 2992396

${ }^{38}$ Kremlin webpage, 30 March 2020

${ }^{39}$ Kremlin webpage, 10 and 12 April 2020

${ }^{40}$ Joint Statement by President Donald J. Trump and President Vladimir Putin of Russia Commemorating the 75th Anniversary of the Meeting on the Elbe, 25 April, https:/www.whitehouse.gov/briefings-statements/ joint-statement-president-donald-j-trump-president-vladimir-putin-russia-commemorating-75th-anniversarymeeting-elbe/

${ }^{41}$ Press Conference by President Obama and President Medvedev of Russia, 6 July, 2009, https:// obamawhitehouse.archives.gov/the-press-office/press-conference-president-obama-and-president-medvedevrussia

42 @mfa russia, 17 April 2020

43 @mfa_russia, 9 April 2020
} 
question regarding the limits of Russia's "soft balancing" as a basis of engagement with China compared to the alternative (multilateral approaches).

Our findings confirm the previously identified unsteady and ambiguous pattern of Sino-Russian cooperation (or, as some have argued, "containment and engagement") [25]. Thus, while it has been suggested that the strength and durability of the SinoRussian alignment "will only be determined under stress" [4, p. 140], the present study demonstrates that COVID-19 has not resolved the ambivalence of the Sino-Russian relationship, which remains situated between an "axis of convenience" and a consolidated strategic partnership underpinned by mutual support.

Funding This study was conducted at the Research Centre in Political Science (UIDB/CPO/00758/2020), University of Minho/University of Évora, and supported by the Portuguese Foundation for Science and Technology (FCT) and the Portuguese Ministry of Education and Science through national funds.

Data Availability The data that support the findings of this study are available from the corresponding author upon reasonable request.

\section{Declarations}

Conflict of Interest The authors declare no competing interests.

\section{References}

1. Adesina, O. S and Summers J. (Reviewing Editor). (2017) Foreign policy in an era of digital diplomacy. Cogent Social Sciences, 3(1).

2. Allison, G. (2018). China and Russia: A strategic alliance in the making. The National Interest, 14.

3. Ambrosio, T. (2005). The Russo-American dispute over the invasion of Iraq: international status and the role of positional goods. Europe-Asia Studies, 57(8), 1189-1210.

4. Ambrosio, T. (2017). The Architecture of Alignment: The Russia-China Relationship and International Agreements, Europe-Asia Studies, 69(1), 110-156.

5. Barash, V., \& Kelly, J. (2012). Salience vs. commitment: Dynamics of political hashtags in Russian Twitter. Berkman Center Research Publication.

6. Baumgartner, S.E \& Wirth, W. (2012). Affective Priming During the Processing of News Articles. Media Psychology, 15(1), 1-18.

7. Bin, Y. (2014). China-Russia Relations:"'Western Civil War Déjà Vu?". Comparative Connections, 16(1), 141.

8. Bolt, Paul J. (2014). Sino-Russian Relations in a Changing World Order. Strategic Studies Quarterly, 8(4), 47-69.

9. Boyd, D., Golder, S., \& Lotan, G. (2010, January). Tweet, tweet, retweet: Conversational aspects of retweeting on twitter. In 2010 43rd Hawaii International Conference on System Sciences, 1-10, IEEE.

10. Budnitsky, S., \& Jia, L. (2018). Branding Internet sovereignty: Digital media and the Chinese-Russian cyberalliance. European Journal of Cultural Studies, 21(5), 594-613.

11. Carlson, B. (2007). The limits of Sino-Russian strategic partnership in Central Asia. Journal of Public and International Affairs, Princeton, 18, 165-187.

12. Carlsson, M., Oxenstierna, S., \& Weissmann, M. (2015). China and Russia: a study on cooperation, competition and distrust. Försvarsanalys, Totalförsvarets forskningsinstitut (FOI).

13. Chaziza, M. (2014). Soft Balancing Strategy in the Middle East: Chinese and Russian Vetoes in the United Nations Security Council in the Syria Crisis. China Report, 50(3), 243-258.

14. Collins, S.D., DeWitt, J.R. \& LeFebvre, R.K. (2019). Hashtag diplomacy: twitter as a tool for engaging in public diplomacy and promoting US foreign policy. Place Brand Public Dipl 15, 78-96. 
15. Dergacheva, D. \& Tous-Rovirosa, A. (2021) Government's echo. Twitter discussions around news topics in Russian networked authoritarianism, Russian Journal of Communication,

16. Duncombe, C. (2017). Twitter and transformative diplomacy: social media and Iran-US relations. International Affairs, 93(3), 545-562.

17. Eder, T.S. (2013). China-Russia relations in Central Asia: energy policy, Beijing's new assertiveness and 21 st century geopolitics. Springer Science \& Business Media.

18. Engelbrekt, K., \& Watts, J. (2015). Sino-Russian Strategic Collaboration: Still an "Axis of Convenience"? Swedish Defence University.

19. Entman, R. M. (2010). Media framing biases and political power: Explaining slant in news of Campaign 2008. Journalism, 11(4), 389-408.

20. Ferguson, C. (2012). The Strategic Use of Soft Balancing: The Normative Dimensions of the ChineseRussian 'Strategic Partnership'. Journal of Strategic Studies, 35(2), 197-222.

21. Flemes, D. (2007). Emerging middle powers' soft balancing strategy: State and perspectives of the IBSA dialogue forum GIGA Research Programme: Violence. Power and Security. GIGA Working Paper No.57.

22. Foreign Affairs. (2020). The Coronavirus Could Reshape Global Order : China Is Maneuvering for International Leadership as the United States Falters, Foreign Affairs https://www.foreignaffairs.com/ articles/china/2020-03-18/coronavirus-could-reshape-global-order

23. Foreign Policy. (2020). The Coronavirus Has Put the U.S.-China Relationship on Life Support, Foreign Policy, https://foreignpolicy.com/2020/03/18/the-coronavirus-has-put-the-u-s-china-relationship-on-lifesupport/

24. Gabuev, A.(2020). The Pandemic Could Tighten China's Grip on Eurasia. Foreign Policy.https:// foreignpolicy.com/2020/04/23/coronavirus-pandemic-china-eurasia-russia-influence/

25. Goh, E. (2006). Understanding 'Hedging' in Asia-Pacific Security, PacNet 43. (August 31).

26. Golbeck, J., Grimes, J.M. and Rogers, A. (2010), Twitter use by the U.S. Congress. J. Am. Soc. Inf. Sci., 61: 1612-1621.

27. Gong, F., Xiong, Y., Xiao, J., Lin, L., Liu, X., Wang, D., \& Li, X. (2020). China's local governments are combating COVID-19 with unprecedented responses - from a Wenzhou governance perspective.

28. Heydarian R.J. (2020). The New Cold War: Sleep-Walking into Great Power Conflict. In: The IndoPacific: Trump, China, and the New Struggle for Global Mastery. Palgrave Macmillan, Singapore.

29. Honey, C., \& Herring, S. C. (2009, January). Beyond microblogging: Conversation and collaboration via Twitter. 42nd Hawaii International Conference on System Sciences 1-10, IEEE.

30. Huang, Z. A., \& Wang, R. (2019). Building a Network to "Tell China Stories Well": Chinese Diplomatic Communication Strategies on Twitter. International Journal of Communication, 13(24), 2984-3007.

31. Hughes, K. (2020). Trump's Twiplomacy - A New Diplomatic Norm? (Dissertation, Malmö universitet/ Kultur och samhälle). Retrieved from http://urn.kb.se/resolve?urn=urn:nbn:se:mau:diva-22515

32. Hurrell, A.(2006). Hegemony, liberalism and global order: what space for would-be great powers?, International Affairs, 82(1), 1-19.

33. Indeo, F. (1998). Russia and China in Central Asia: growing geopolitical competition. International Affairs, 16.

34. Kaczmarski, M. (2019, August). Russia-China relations in Central Asia: why is there a surprising absence of rivalry? In Open Forum. Asan Forum.

35. Kaczmarski, M. (2019, Jul 16). The future of Russia-China relations, China's Global Role, Russia 2030 Atlantic community.

36. Karaganov, S. and Makarov I. (2014, 18 January). Strategy XXI: Pivot East. vedomosti.https://www. vedomosti.ru/newspaper/articles/2014/01/28/povorot-na-vostok

37. Kelly, J., Barash, V., Alexanyan, K., Etling, B., Faris, R., Gasser, U., \& Palfrey, J. G. (2012). Mapping Russian Twitter. Berkman Center Research Publication.

38. Kim, Y., \& Blank, S. (2013). Rethinking Russo-Chinese Relations in Asia: Beyond Russia's Chinese Dilemma. China: An International Journal, 11(3), 136-148.

39. Korolev, A. (2015). The strategic alignment between Russia and China: Myths and reality. Lee Kuan Yew School of Public Policy Research Paper, 15-19.

40. Korolev, A. (2016). Systemic balancing and regional hedging: China-Russia relations. The Chinese Journal of International Politics, 9(4), 375-397.

41. Korolev, A. (2019). On the Verge of an Alliance: Contemporary China-Russia Military Cooperation. Asian Security, 15(3), 233-252.

42. Korolev, A., \& Portyakov, V. (2018). China-Russia Relations in Times of Crisis: A Neoclassical Realist Explanation. Asian Perspective 42(3), 411-437. 
43. Kragh, M. \& Åsberg, S. (2017). Russia’s strategy for influence through public diplomacy and active measures: the Swedish case. Journal of Strategic Studies, 40(6), 773-816.

44. Kuchins, A. C. (2009). Releveraging US power amid Sino-Russian rapprochement. Chinese Soft Power and Its Implications for the United States Competition and Cooperation in the Developing World, 116134.

45. Kuznetsov, D. V. (2016). China and the Ukrainian Crisis: From 'Neutrality' to 'Support' for Russia. China Report, 52(2), 92-111.

46. Larson, D. W. (2019). An equal partnership of unequals: China's and Russia's new status relationship. International Politics, 1-19.

47. Lewandowsky, S., Jetter, M. \& Ecker, U.K.H. (2020). Using the president's tweets to understand political diversion in the age of social media. Nature Communications 11(1) 1-12 .

48. Light M. (2015). Russian Foreign Policy Themes in Official Documents and Speeches: Tracing Continuity and Change. In: Cadier D., Light M. (eds) Russia's Foreign Policy. Palgrave Studies in International Relations Series. Palgrave Macmillan, London.

49. Lo, B. (2009). Axis of convenience: Moscow, Beijing, and the new geopolitics. Brookings Institution Press.

50. Lubina, M. (2017). Russia and China: A political marriage of convenience-stable and successful. Verlag Barbara Budrich.

51. Lukin, A. (1999). Russia's image of China and Russian-Chinese relations. East Asia, 17(1), 5-39.

52. MacHaffie, J.(2011). The Potential for a China-Russia Military Alliance Explored. Alternatives: Turkish Journal of International Relations, 10 (2/3), 21-44.

53. Manheim, J., \& Albritton, R. (1984). Changing National Images: International Public Relations and Media Agenda Setting. American Political Science Review, 78(3), 641-657.

54. Manor, I. and Segev, E. (2020), Social Media Mobility: Leveraging Twitter Networks in Online Diplomacy. Global Policy, 11, 233-244.

55. Martins, B. O. (2016). Interpreting EU-Israel relations: a contextual analysis of the EU's Special Privileged Partnership proposal. Cambridge Review of International Affairs, 29(1), 151-170.

56. McNelly, J. T., \& Izcaray, F. (1986). International News Exposure and Images of Nations. Journalism Quarterly, 63(3), 546-553.

57. Michalski, A., and Pan, Z. (2017). Role dynamics in a structured relationship: the EU-China strategic partnership. JCMS: Journal of Common Market Studies, 55(3), 611-627.

58. Novayagazeta.(2020). Посольство Китая попросило прекратить проверки китайских граждан в общественном транспорте Москвы (ДОКУМЕНТ), Novaya Gazeta. https:/novayagazeta.ru/news/ 2020/02/25/159339-posolstvo-kitaya-poprosilo-prekratit-proverki-kitayskih-grazhdan-vobschestvennom-transporte-moskvy

59. NY Times (2020). https:/www.nytimes.com/2020/02/07/health/cdc-coronavirus-china.html

60. Oates, S., \& Gray, J. (2019). \# Kremlin: Using Hashtags to Analyze Russian Disinformation Strategy and Dissemination on Twitter. Available at SSRN 3445180.

61. Pape, R. A. (2005). Soft Balancing against the United States. International Security, 30(1), 7-45.

62. Paul, T.V.(2004). Introduction: The enduring axioms of balance of power theory and their contemporary relevance. Balance of power: theory and practice in the 21 st century, 1-25. ed. T. V. Paul, J. J. Wirtz, and M. Fortmann. Stanford University Press.

63. Pavón-Guine, A. (2018) The empirical factors of Twitter adoption by world governments: the impact of regime type and time on diffusion, The Journal of International Communication, 24(1), 138-161.

64. Peake, J. S., \& Eshbaugh-Soha, M. (2008). The agenda-setting impact of major presidential TV addresses. Political Communication, 25(2), 113-137.

65. Permyakova, L. (2012). RIAC: Digital diplomacy: areas of work, risks and tools. https://russiancouncil. $\mathrm{ru} / \mathrm{en} /$ analytics-and-comments/analytics/digital-diplomacy-areas-of-work-risks-and-tools/ (also in https:// www.kommersant.ru/doc/198153)

66. Person, R. (2001). Crouching tiger, hidden jargon: The Sino-Russian strategic partnership. Stanford Journal of International Relations, 3(1).

67. Petro, N. N. (2018). How the West Lost Russia: Explaining the Conservative Turn in Russian Foreign Policy, Russian Politics, 3(3), 305-332.

68. Popping, R. (2000). Computer-assisted text analysis. Sage.

69. Rathnayake, C., \& Suthers, D. D. (2018). Twitter Issue Response Hashtags as Affordances for Momentary Connectedness. Social Media Society.

70. Simons, G. (2014). Russian public diplomacy in the 21 st century: Structure, means and message. Public Relations Review, 40(3), 440-449. 
71. Šmunjak, M. \& Alessandro Caliandro (2019) Twiplomacy in the age of Donald Trump: Is the diplomatic code changing?, The Information Society, 35:1, 13-25.

72. Snijders, C. (1996). Trust and commitments (Vol. 33). Purdue University Press.

73. Soroka, S. N. (2003). Media, Public Opinion, and Foreign Policy. Harvard International Journal of Press/Politics, 8(1), 27-48.

74. South China Morning Post (2020). Russia and China pledge to maintain special relationship despite Moscow's slow response to coronavirus. (quoted in the text by Li Lifan from the Shanghai Academy of Social Sciences) https://www.scmp.com/news/china/diplomacy/article/3050782/russia-and-china-pledgemaintain-special-relationship-despite

75. Stone, J. (1997). Thematic text analysis-New agendas for analyzing text content. Test analysis for the social sciences-Methods for drawing statistical inferences from texts and transcripts, 35-54.

76. Surma, I. (2016). Pushing the boundaries of digital diplomacy: The international experience and the Russian practice. In International Conference on Cyber Warfare and Security (p. 304). Academic Conferences International Limited.

77. Tass .(2020a). Sochi investment forum organizers to submit their proposals on new possible dates. https://tass.com/russia/1116057

78. Tass .(2020b). Russia to send humanitarian aid to China to fight coronavirus, https://tass.com/society/ 1115611

79. Tass .(2020c) . Kremlin urges not to exaggerate impact of US-China trade war on Russia. https://tass. com/economy/1058105

80. Tsvetkova, N. (2020). Russian digital diplomacy: A rising cyber soft power?. In Russia's Public Diplomacy (pp. 103-117). Palgrave Macmillan, Cham.

81. Tsvetkova, N. \& Rushchin, D. (2021) Russia's Public Diplomacy: From Soft Power to Strategic Communication, Journal of Political Marketing, 1-12.

82. Twiplomacy Study 2018. https://twiplomacy.com/blog/twiplomacy-study-2018/

83. Tyushka, A., Czechowska, L., Domachowska, A., Gawron-Tabor, K., \& Piechowiak-Lamparska, J. (2019). States, international organizations and strategic partnerships: theorizing an 'ideal model'. In States, International Organizations and Strategic Partnerships. Edward Elgar Publishing.

84. Van de Ven, J. (2020). Fair-Weather Friends: The Impact of the Coronavirus on the Strategic Partnership Between Russia and China. China Brief, 20(4).

85. Vieira, A. (2016). Ukraine, Russia and the strategic partnership dynamics in the EU's eastern neighbourhood: recalibrating the EU's 'self','we' and 'other'. Cambridge Review of International Affairs, 29(1), 128-150.

86. Walt, Stephen M. (2005). Taming American power: The global response to U.S. primacy. New York: Norton.

87. Wenzhao, T., \& Shengwei, X. (2020). The US factor in post-cold war China-Russia relations. International Politics, 1-23.

88. Wimmer, R.D., \& Dominick, J.R. (1994). An introduction to mass media research. California: Wadsworth.

89. Wishnick, E. (2017). In search of the 'Other' in Asia: Russia-China relations revisited. The Pacific Review, 30(1), 114-132.

90. Wlezien, C. (2005). On the salience of political issues: The problem with 'most important problem'. Electoral studies, 24(4), 555-579.

91. WORDSTAT (version8). https://provalisresearch.com/products/content-analysis-software/

92. Xinhua.(2020). China publishes timeline on COVID-19 information sharing, int'l cooperation. http:// www.xinhuanet.com/english/2020-04/06/c_138951662.htm

93. Zeitzoff T, Kelly J, Lotan G. Using social media to measure foreign policy dynamics: An empirical analysis of the Iranian-Israeli confrontation (2012-13). Journal of Peace Research. 2015;52(3):368-383.

94. Zhang Sheng (2020). In Search of Solidarity: The Coronavirus and China's Views of the UAE and Iran. FIKRA Forum. The Washington Institute.

95. Zhenming, Z., \& Yanqi, Y. (2020). Alliance Forging or Partnership Building? China's Policy in the AsiaPacific under the Xi Administration. The International Spectator, 55(1), 62-77.

Publisher's Note Springer Nature remains neutral with regard to jurisdictional claims in published maps and institutional affiliations. 